\title{
Liver Glucocorticoid Receptor and Heat Shock Protein 70 Levels in Rats Exposed to Different Stress Models
}

\author{
D. FILIPOVIĆ, L. GAVRILOVIĆ, S. DRONJAK, M. DEMAJO, M. B. RADOJČIĆ \\ "Vinča" Institute of Nuclear Sciences, Laboratory of Molecular Biology and Endocrinology, \\ Belgrade, Serbia
}

Received November 7, 2006

Accepted April 2, 2007

On-line available May 30, 2007

\section{Summary}

The aim of the present study was to define the stress-induced pattern of cytosolic glucocorticoid receptor (GR) and Hsp70 protein in the liver of male Wistar rats exposed to different stress models: acute $\left(2 \mathrm{~h} /\right.$ day) immobilization or cold $\left(4^{\circ} \mathrm{C}\right)$; chronic (21 days) isolation, crowding, swimming or isolation plus swimming and combined (chronic plus acute stress). Changes in plasma levels of corticosterone were studied by radioimmunoassay (RIA). The results obtained by Western immunoblotting showed that both acute stressors led to a significant decrease in cytosolic GR and Hsp70 levels. Compared to acute stress effects, only a weak decrease in the levels of GR and Hsp70 was demonstrated in chronic stress models. Chronically stressed rats, which were subsequently exposed to novel acute stressors (immobilization or cold), showed a lower extent of GR down-regulation when compared to acute stress. The exception was swimming, which partially restores this downregulation. The observed changes in the levels of these major stress-related cellular proteins in liver cytosol lead to the conclusion that chronic stressors compromise intracellular GR down-regulation in the liver.

\section{Key words}

Rat • Liver • Stress • Glucocorticoid receptor - Heat shock protein 70

\section{Corresponding author}

D. Filipović, "Vinča" Institute of Nuclear Sciences, Laboratory of Molecular Biology and Endocrinology, P.O.Box 522-090, 11000 Belgrade, Serbia. Fax: +381 (11) 2455-561. E-mail: dragana@vin.bg.ac.yu

\section{Introduction}

Glucocorticoids (GCs) are involved in the regulation of various physiological processes that are essential for the maintenance of vital functions. These hormones are necessary for normal growth and development, liver and immune functions as well as in mediating stress responses (Sapolsky et al. 2000). The biological actions of GCs are dependent upon tissuespecific levels of the glucocorticoid receptor (GR). GR exists in the cytoplasm of target cells in the form of multiprotein complexes containing several heat shock proteins (Hsps) and additional components of the molecular chaperon family (Pratt and Toft 1997). Upon steroid binding, the GR is translocated into the cell nucleus where it acts as a ligand-induced transcription factor (Caamano et al. 2001). The steroid receptors are associated predominantly with Hsp70 (Hightower and Hendershot 1997), which has the chaperoning role in protein folding (Hendrick and Hartl 1993) and nuclear import (Shi and Thomas 1992). Furthermore, the expression of Hsp70 is related to the preservation and recovery of cellular proteins under the stress (Benjamin and McMillan 1998).

Tissue sensitivity to hormone signals is directly related to the levels of circulating cortisol and the number of GR found in cells (Oakley and Cidlowski 1993, Dong et al. 1988). In addition, it has been shown that animals chronically exposed to a particular stressor display an exaggerated response of the hypothalamopituitary-adrenal (HPA) axis to various novel stressors, judged by plasma levels of the adenocorticotropic hormone and corticosterone (CORT) (McEwen 1998, 
Garcia et al. 2000, Sapolsky et al. 1984). The exaggerated effect of novel stressors is an interesting phenomenon that has not been studied at the level of GR and Hsp70 in the liver. Recently, we have shown that significant down-regulation of GR levels in acute stress was almost completely compromised by chronic stressors alone, or in combination with novel acute stressors, in higher centers of the HPA axis, i.e. brain cortex and hippocampus (Filipović et al. 2005). Since the liver is a well-studied target for GCs, we have chosen this organ to examine the effects of different stress models (Filipović et al. 2005) on the levels of GR in the liver cytosol and to reveal if these stress models influence the intracellular cytosolic GR regulation. Considering that GCs stimulate the synthesis of heat shock proteins under basal conditions (Kasambalides and Lanks 1983), it was of interest to investigate if these hormones might influence the levels of Hsp70 during the various stress models applied in this investigation. Therefore, the present study was conducted to define the stress-induced pattern of GR and Hsp70 protein in the liver cytosol of adult Wistar male rats exposed to acute (immobilization or cold), chronic (isolation, crowding, swimming or isolation plus swimming) or combined (chronic plus acute) stress models. Plasma CORT levels were also monitored. It was expected that patterns of cytosolic GR and Hsp70 in the liver of stressed rats could be one of the cytosolic parameters that may serve to distinguish between stress duration (acute, chronic), stress intensity (by protein expression level) or type (psychosocial, physical).

\section{Materials and Methods}

\section{Animals and stress models}

Adult Wistar rat males, weighing 330-400 g were housed in groups of four individuals per cage and offered water and food (commercial rat pellets) ad libitum. The light was kept on between 7:00 and 19:00 $\mathrm{h}$, the room temperature was set at $20 \pm 2{ }^{\circ} \mathrm{C}$. The animal experiments were approved by the Ethical Committee for the Use of Laboratory Animals of the "Vinča" Institute which works according to the guidelines of the registered "Serbian Society for the Use of Animals in Research and Education". For experimental purposes, the animals were randomly divided into 10 groups (6-8 animals in each group). Group I consisted of unstressed animals (control group), Group II was exposed to acute stress by $2 \mathrm{~h}$ of immobilization (IIa) or cold (IIb) $\left(4^{\circ} \mathrm{C}\right)$,
Group III was exposed to chronic isolation, i.e. the rats were individually housed for 21 days and Group IV was exposed to chronic crowding for 21 days, with eight animals per cage. Group V comprising four animals per cage was exposed to chronic forced $15 \mathrm{~min} /$ daily swimming for 21 days, Group VI was subjected to chronic isolation plus $15 \mathrm{~min} /$ daily swimming for 21 days. Animals exposed to either of the four chronic stressors (groups III-VI) were subsequently exposed to immobilization or cold $\left(4^{\circ} \mathrm{C}\right)$ for $2 \mathrm{~h}$ (isolation plus immobilization or cold VIIa/VIIb, crowding plus immobilization or cold VIIIa/VIIIb, swimming plus immobilization or cold IXa/IXb, isolation/swimming plus immobilization or cold $\mathrm{Xa} / \mathrm{Xb}$ ). Immobilization stress was induced as described by Kvetňanský and Mikulaj (1970). The animals exposed to cold were initially kept at ambient temperature $\left(20 \pm 2{ }^{\circ} \mathrm{C}\right)$ and then carefully transferred into a cold chamber at $4{ }^{\circ} \mathrm{C}$ with lights on.

\section{Preparation of rat blood plasma and liver cell extracts}

The blood sampling for determining plasma corticosterone (CORT) content was described in detail previously (Dronjak et al, 2004). Plasma CORT was measured using the radioimmunoassay (RIA) commercial kit (ICN, Biochemical, Costa Mesa, CA, USA) and the values were expressed as ng/ml. All samples were measured in duplicate in the same assay. The variation between duplicate samples was less than 7 $\%$. The lowest detectable limit of hormone detection in this assay system is $25 \mathrm{ng} / \mathrm{ml}$.

Unstressed controls or stressed animals were sacrificed $2 \mathrm{~h}$ after the end of the stress procedure by decapitation with a guillotine (Harvard Apparatus, South Natick, MA. USA). The livers were rapidly perfused in situ with ice-cold $50 \mathrm{mM}$ Tris- $\mathrm{HCl}$ buffer, $\mathrm{pH} 7.55$, containing $0.25 \mathrm{M}$ sucrose, $25 \mathrm{mM} \mathrm{KCl}, 10$ $\mathrm{mM} \mathrm{MgCl}_{2}$ and protease-inhibitor cocktail $(1.0 \mathrm{mM}$ DTT, $0.1 \mathrm{mM}$ PMSF, $5 \mu \mathrm{g} / \mathrm{ml}$ aprotinin), excised, placed on ice, rinsed with ice-cold buffer, weighed and homogenized in $2 \mathrm{vol}(\mathrm{w} / \mathrm{v})$ of the same buffer by 10 strokes in the Potter-Elvehjem teflon-glass homogenizer. The homogenates were centrifuged (10 min, $10000 \mathrm{rpm}, 4{ }^{\circ} \mathrm{C}$ ) and the resulting supernatants were centrifuged again (60 min, $45000 \mathrm{rpm}, 4{ }^{\circ} \mathrm{C}$; Beckman L8-M Ultracentrifuge) to obtain purified cell cytosol. The protein content was determined by the method of Lowry et al. (1951) using bovine serum albumin (BSA, Sigma Aldrich) as a reference. The 
samples were mixed with denaturing buffer according to Laemmli (1970) and kept at $-70{ }^{\circ} \mathrm{C}$ before the analysis.

Separation of proteins by SDS-polyacrylamide gel electrophoresis and quantification by immunoblotting

Aliquots of liver cytosols were boiled $\left(100{ }^{\circ} \mathrm{C}\right.$, $2 \mathrm{~min}$ ), cooled and analyzed on $10 \%$ SDS-polyacrylamide gels using a Mini-Protean II Electrophoresis Cell (Bio-Rad Laboratories, Hercules CA, USA) according to Laemmli (1970). The gel calibration and Western transfer of proteins to nitrocellulose membranes were performed as described previously (Wrange et al. 1984). The membrane was incubated overnight $\left(4{ }^{\circ} \mathrm{C}\right)$ with either monoclonal anti-rat glucocorticoid receptor antibodies Ab-2 (GR32L, Clone BuGR2; $5 \mu \mathrm{g} / \mathrm{ml}$ TBST; Oncogene Research Product, San Diego, CA, USA) or monoclonal anti-human Hsp70 antibodies conjugated to alkaline phosphatase $(1: 500=$ antibodyTBST buffer; Calbiochem, La Jolla, CA, USA). The anti-human Hsp70 antibody recognized both the constitutive and inducible Hsp70 form (Čvoro et al. 1998). In the case of BuGR2, the secondary antibody conjugated to alkaline phosphatase (ImmunoReporter $^{\mathrm{TM}}$ Reagent DC05L, Oncogene Research Products, San Diego, CA, USA) was used for detection. The $\beta$-actin was used as an appropriate loading control. The blots were stripped with $0.1 \mathrm{M}$ glycine- $\mathrm{HCl}$ ( $\mathrm{pH}$ 2.8) twice for $30 \mathrm{~min}$ at $60{ }^{\circ} \mathrm{C}$ and SDS $2 \%$ for $10 \mathrm{~min}$, followed by overnight saturation in $4 \%$ BSA at $4{ }^{\circ} \mathrm{C}$. They were then incubated with primary polyclonal goat anti-actin antibody (SC-1616; Santa Cruz Biotehnology) followed with alkaline phosphatase conjugated secondary anti-goat IgG antibody. The quantification of specific antigen bands was achieved by GelDoc scanning and PC processing. The levels of GR and Hsp70 in stressed animals were expressed as \% change in relation to those in unstressed animals taken as $100 \%$ (controls).

\section{Statistical analysis}

The data were presented as means \pm S.E.M. of 5-6 animals per group. The obtained data were analyzed by two-way ANOVA (the factors were acute or chronic stress, and the levels for the acute stress were none, immobilization, cold, and for the chronic stress were none, isolation, crowding, swimming, isolation plus swimming). The Tukey post-hoc test was used to evaluate the differences between the groups. Statistical significance was accepted at $\mathrm{p}<0.05$.

\section{Results}

Levels of GR and Hsp70 in liver of animals subjected to acute, chronic and combined stress models.

In order to examine the influences of acute, chronic and combined stressors on the change in the levels of the GR and the Hsp70, we performed SDSPAGE electrophoresis and Western blot of rat liver cytosol obtained from stressed and compared with unstressed control rats. The results of Western immunoblotting of both proteins in the liver cytosol are presented in Figure 1. The lanes of Western blot images of GR and Hsp70 are presented in Figure 2.

Two-way ANOVA showed that animal exposure to either of the acute stressors, immobilization or cold, resulted in a significant down-regulation of GR levels $\left(\mathrm{F}_{2,60}=44.60, \mathrm{p}<0.001\right)$ and Hsp70 levels $\left(\mathrm{F}_{2,60}=42.56, \mathrm{p}<\right.$ 0.001 ) (Fig. 1, left panel). Both acute stressors induced a similar down-regulation of GR levels $(p<0.001)$, compared to the unstressed controls, in spite of the differences in the type and the intensity of the acute stressor. The changes of Hsp70 levels in these models closely followed the changes in levels of cytosolic GR.

Compared to acute stress effects, chronic stress led to a mild decrease in levels of GR $\left(\mathrm{F}_{4,60}=17.60, \mathrm{p}<\right.$ $0.001)$ and $\operatorname{Hsp} 70\left(\mathrm{~F}_{4,60}=8.19, \mathrm{p}<0.001\right)$. In the group of chronic stressors, swimming or isolation plus swimming were the stressors that led to a significant decrease in the cytosolic GR levels ( $\mathrm{p}<0.001)$, (Fig. 1, middle panel). On the other hand, two chronic stressors such as isolation or crowding did not change the cytosolic GR levels ( $p>0.05$ ), when compared to the unstressed controls (Fig. 1, middle panel). In addition, the levels of GR and Hsp70 after applying all chronic stressors were significantly different from their levels after acute stress $(p<0.05)$. The only exception was the chronic isolation plus $15 \mathrm{~min} /$ daily swimming as compared to acute stress immobilization ( $\mathrm{p}>0.05)$.

Rats that had been subjected to chronic stressors and then exposed to acute stressors, exhibited a significant down-regulation of hepatic GR $\left(\mathrm{F}_{8,60}=19.20, \mathrm{p}<0.001\right)$ and Hsp70 levels $\left(\mathrm{F}_{8,60}=3.26, \mathrm{p}<0.01\right)$ (Fig. 1, right panel). The intensity of this down-regulation decreased to a lower extent when compared to the acute stressors. The levels of GR and Hsp70 were between the values obtained after acute or chronic stresses alone. The only exception occurred the GR level after chronic crowding followed by immobilization $(p>0.05)$. The levels of GR after combined stressors were significantly different from their levels after 


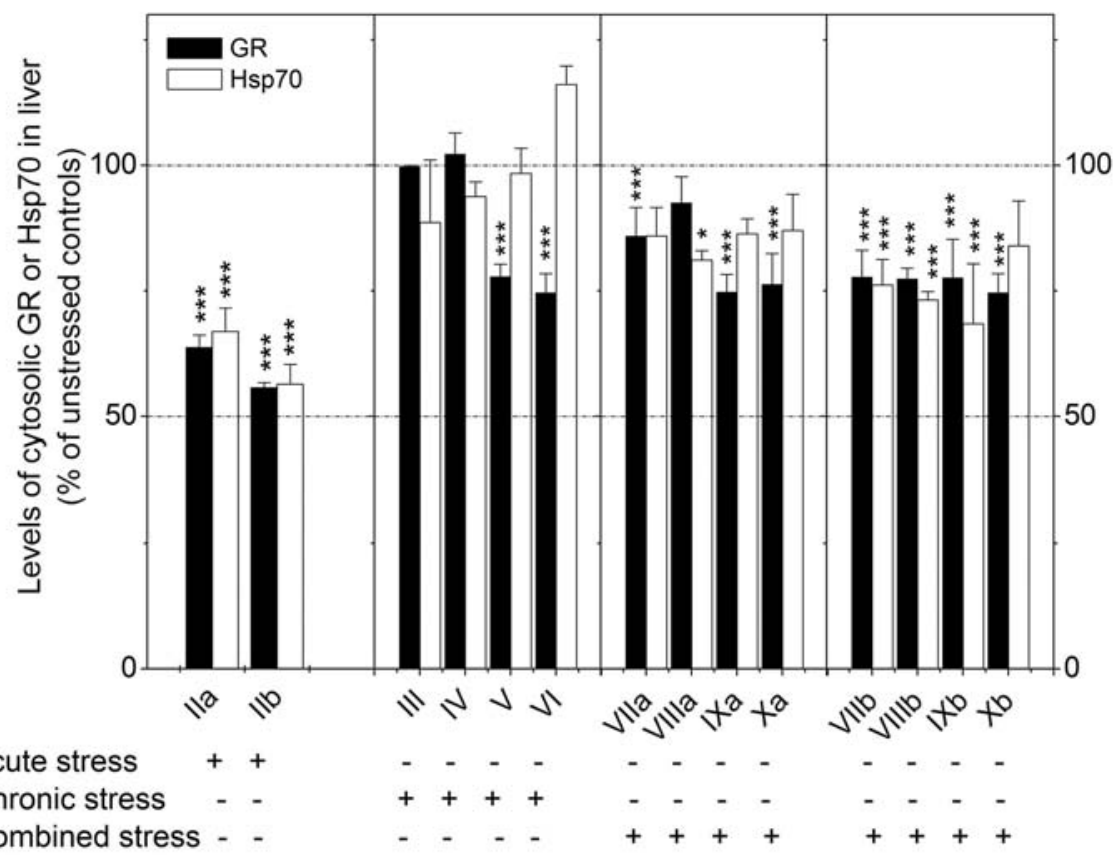

A
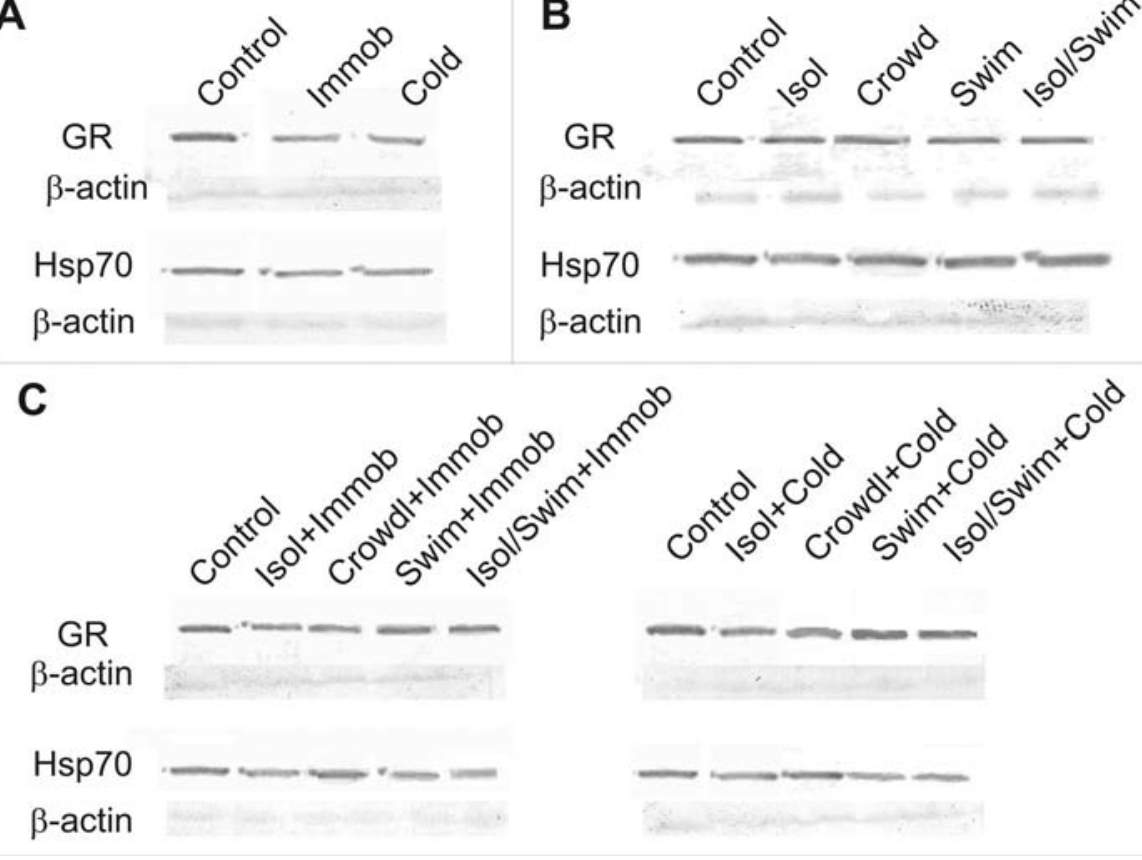

B

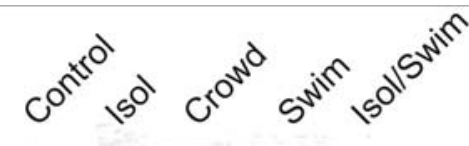

GR

$\beta$-actin

Hsp70

$\beta$-actin

Fig. 1. Relative changes, expressed as $\%$ of unstressed controls, in the levels of glucocorticoid receptor (GR) and heat shock protein 70 (Hsp70) in the liver of animals exposed to acute stressors: immobilization (IIa) or cold (IIb); chronic stressors: isolation (III), crowding (IV), swimming (V), isolation plus swimming (VI) or combined stressors such as: isolation plus immobilization or cold VIIa/VIIb, crowding plus immobilization or cold VIIIa/VIIIb, swimming plus immobilization or cold $\mathrm{IXa/IXb}$ isolation/swimming plus immobilization or cold $\mathrm{Xa} / \mathrm{Xb}$, as indicated. The results are shown as the mean \pm S.E.M. Asterisks indicate a significant difference between the respective stress groups and unstressed controls; ${ }^{*} p<0.05$ and ${ }^{* * *} p<0.001$ by Tukey post-hoc test.

Fig. 2. Western blot images of specific immunoreactivity of antibodies to glucocorticoid receptor (GR) and heat shock protein 70 (Hsp70) in the liver cytosol of control animals and animals exposed to A - acute stressors immobili-zation (Immob) or cold; B chronic stressors isolation (Isol), crowding (Crowd), swimming (Swim), isolation plus swimming (Isol/Swim) and C-combined stressors as indicated. Data are presented as described in the legend of Fig. 1. acute stressors $(p<0.01)$. The only exception was in the case of chronic swimming or isolation plus swimming followed by immobilization ( $\mathrm{p}>0.05$ ). In the case of Hsp70 levels, the combined stress of chronic isolation, crowding or swimming followed by cold were most effective in down-regulating of this protein level $(\mathrm{p}<0.001)$ (Fig. 1, right panel). The levels of Hsp70 after all the combined stressors were closer to those of acute stress and a significant difference between combined and acute stress was observed only after chronic isolation plus swimming followed by cold $(\mathrm{p}<0.05)$.
Plasma levels of corticosterone in stressed animals

The plasma levels of corticosterone (CORT) were also determined in all stressed animal groups (Fig. 3). In the acutely stressed animals, levels of CORT in the blood plasma were significantly increased $\left(\mathrm{F}_{2,75}=675.90, \mathrm{p}<0.001\right)$. Acute exposure to immobilization resulted in a 6 -fold increase of plasma CORT levels, in relation to the unstressed controls. Furthermore, cold as acute stress led to a 3-fold increase of CORT level, in relation to the unstressed controls.

Evaluation of chronic stress data indicated 


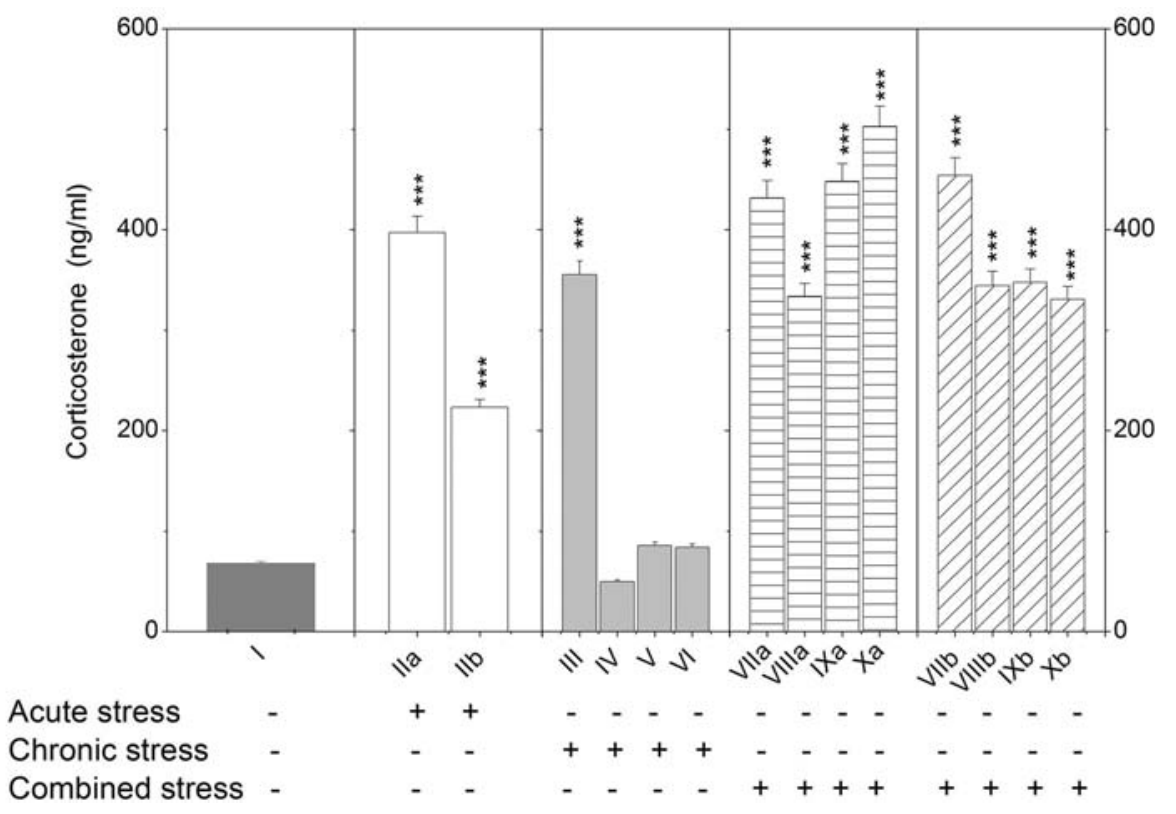

Fig. 3. Plasma levels of corticosterone (CORT) $(\mathrm{ng} / \mathrm{ml})$ in the control animals and animals exposed to acute stressors: immobilization (IIa) or cold (IIb); chronic stressors: isolation (III), crowding (IV), swimming (V), isolation plus swimming (VI) or combined stressors such as: isolation plus immobilization or cold VIIa/VIIb, crowding plus immobilization or cold VIIIa/VIIIb, swimming plus immobilization or cold IXa/IXb, isolation/swimming plus immobilization or cold $\mathrm{Xa} / \mathrm{Xb}$, as indicated. The results are shown as the mean \pm S.E.M. Asterisks indicate a significant difference between the respective stress groups and unstressed controls; ${ }^{* *} p<0.001$ by Tukey post-hoc test.

significant changes of plasma CORT levels $\left(\mathrm{F}_{4,75}=94.80\right.$, $\mathrm{p}<0.001)$. Out of the chronic stressors, isolation induced the most significant increase of plasma CORT levels $(p<0.001)$, while other types of chronic stressors showed a relatively weak activation of the CORT secretion system which was not significant, when compared to unstressed controls.

Exposure of chronically stressed rats to novel stressors (immobilization or cold) induced an exaggerated response in plasma CORT levels $\left(\mathrm{F}_{8,75}=32.70, \mathrm{p}<0.001\right)$. Statistical analysis showed a 5-8 fold increase of CORT levels, when compared to unstressed controls (Fig. 3, right panel). When the results of the combined stress models were compared to those of acute stress models, it was observed that the additional acute cold stress, which resulted in a significant increase of CORT content, induced a highly significant difference $(\mathrm{p}<0.001)$, while the differences between combined and acute immobilization stress were slightly less significant $(\mathrm{p}<0.01)$.

\section{Discussion}

Glucocorticoids (GCs) and heat shock proteins (Hsp) are essential for normal growth, differentiation and development as well as for adaptation and survival of cells and organisms under stressors of various origin. Considering that the various stress models lead to an increase in the levels of GCs, the understanding of GCs actions via GR in different stress models is important to attain a more effective insight into the pathophysiology of stress-related diseases. Since the GCs are an important factor in the regulation of Hsp70 levels during the maintenance of homeostasis, it is of special interest to know if various stress models may potentially modulate the heat shock response.

In our study, the most intensive decrease in the level of cytosolic GR and Hsp70 was observed in acutely stressed animals. As can be seen from Figure 1, the pattern of both cytosolic proteins was similar for both acute stressors. This might be explained by the existence of a functional relationship between the heat shock response and GR action. At the same time, cold or immobilization stress induced marked 3- to 6-fold elevations of plasma corticosterone (CORT) levels. The observed rise in CORT levels resembles the data of other authors (Alexandrová 1994, Meaney et al. 1991) who found that the acute immobilization stress on SpragueDawley rats resulted in a 3- to 4-fold elevation in plasma CORT levels. The decrease in the levels of cytosolic GR and Hsp70 in the rat liver after acute elevation of GCs, is due to the translocation of cytosolic GR to the nucleus (Caamano et al. 2001) or its transcriptional downregulation (Dong et al. 1988, Schaaf and Cidlowski 2002). The results on molecular mechanisms of GCs action showed that at least three mechanisms could be involved in the down-regulation of GR. Down-regulation may be partially controlled at the transcriptional level (Rosewicz et al. 1988) so that GCs administration reduced GR mRNA levels in adult rats (Kalinyak et al. 1987). Besides, the repression of GR gene expresion may be independent of the GR promoter and the sequences 
outside GR promoter region were involved in downregulation of GR (Okret et al. 1986). Finally, a rapid decrease in receptor levels is due to a decrease in GR protein half-life (Silva et al. 1994) probably due to hormone-induced degradation of GR by the proteasome complex (Wallace and Cidlowski 2001, Boone and Vijayan 2002). Concerning the cytosolic levels of Hsp70, its significant decrease in acute stress conditions may include either its decreased synthesis as GCs inhibits Hsp70 transcription via HSF1 (Wadekar et al. 2001) and/or its increased degradation (Boone and Vijayan 2002). It is also interesting to note that plasma CORT levels in animals stressed by acute immobilization were threefold above the level of acutely cold stressed animals and did not influence the intensity of GR and Hsp70 levels. This discrepancy was explained by the floor effect in which minimal levels of constitutive GR production exists (Sapolsky et al. 1984, Wang et al. 1998).

Opposite to the acute stressors, chronic stress conditions led to a slight decrease in the levels of GR and Hsp70. At first glance, it seems that the animals were accommodating to the mild chronic stress, especially in the group of animals exposed to isolation or crowding (psychosocial stress), judging by the GR and Hsp70 levels. The most significant decrease of GR levels was found in chronic swimming or isolation plus swimming stress. These findings could be related to the data of Alexandrová and Farkaš (1992) who found that 15 days of repeated swimming stress resulted in down-regulation of GR in the rat liver. It seems that the swimming or isolation plus swimming stressor as simultaneous psychosocial and physical stress were lower in intensity than isolation or crowding as psychosocial stressors, as judged from the cytosolic levels of GR. In addition, swimming in combination with isolation may diminish detrimental effects of chronic isolation stress, judging by the nearly preserved down-regulation of cytosolic GR levels, although this helpful effect was not observed in the case of Hsp70 levels (Filipović et al. 2007). In the case of Hsp70, chronic stress showed a slight decrease of this protein level and had a tendency to increase under chronic isolation plus swimming stress. It may be speculated that the regulation of Hsp70 is separate from GR regulation in simultaneous psychosocial and physical stress. At the same time, chronically stressed rats subjected to crowding did not show changes in plasma CORT levels, swimming or isolation plus swimming showed a relatively weak activation of the CORT secretion system. On the other hand, chronically isolated animals showed 5-fold increased CORT levels, when compared to the unstressed controls. At the intracellular level, CORT induced down-regulation of GR and Hsp 70. Since the intensity of down-regulation of GR in chronic isolation was less pronounced than its down-regulation under acute stress, it may be suggested that GR may be structurally affected yielding the non-functional receptor unable to interrupt chronic stress CORT signal by its own down-regulation. Furthermore, oxidative stress occurring in chronic isolation (Filipović and Radojčić 2005) may lead to oxidation of GR sulfhydryl groups and their functional alteration (Elez et al, 2000).

Chronically stressed rats, which were subsequently exposed to novel acute stressors (immobilization or cold), showed significantly elevated plasma CORT levels, when compared to chronic stressors. This is in agreement with the findings of Hashiguchi et al. (1997) who suggested that CORT is especially sensitive to novel treatment. The difference in plasma CORT levels between combined and acute cold stress was highly significant, while the differences between combined and acute stress immobilization were less significant. At the same time, combined stress models showed a lower extent of GR and Hsp70 downregulation as compared to acute stress models. The magnitude of these changes for GR protein was between values obtained for acute or chronic stress alone. There were highly significant differences of GR protein levels between combined and acute stress, while the differences between combined and chronic stress were less significant. These still high levels of cytosolic GR and Hsp70 after subsequent application of both acute stressors could result from impaired nucleocytoplasmic shuttling of GR under chronic stress leading to the incomplete down-regulation of GR and Hsp70. Our results suggest that impaired translocation of cytosolic GR to the nucleus after all chronic stressors, compromise signaling transduction of consecutive acute stressors. It is interesting to speculate that chronic stress-induced effects might reflect alterations in the GR and Hsp70 phosphorylation status which is casually linked to its nucleocytoplasmic shuttling (DeFranco et al. 1991, Rouse et al. 1994). In addition, the phospho-deficient mutant of mouse GR does not undergo ligand-dependent down-regulation (Webster et al. 1997). Although the precise mechanism of regulation of Hsp70 expression is not well understood, it seems, at least taking into consideration the stress models in this investigation, that both GR and Hsp70 were mutually inter-regulated (Čvoro 
et al. 1998) or co-regulated by co-activators (Jonat et al. 1990, McKay and Cidlowski 1998, Doucas et al. 2000) concerning both their pattern levels, as well as their stress-dependent pattern.

Finally, the changes of GR levels in chronic or combined stress, lead to the conclusion that, in addition to the hypothalamo-pituitary-adrenal (HPA) axis (Filipović et al. 2005), chronic stressors also compromise intracellular GR down-regulation in the liver. In addition, GR and Hsp70 levels, the major stress-related cellular proteins in the liver, could serve as cytosolic parameters for the distinction between acute and chronic stress, rather than stress intensity or type. Since the GCs stimulate the process of hepatic gluconeogenesis, resulting in elevated plasma glucose (Rizza et al. 1982), and promote the deposition of liver glycogen by the expression of genes of the phosphoenolpyruvate carboxykinase (Imai et al. 1993), incomplete downregulation of GR after chronic stress as well as high levels of GCs may result in significant metabolic and physiological perturbations in this organ as well as in the stressed organism as a whole. Knowing that CuZnSOD expression is regulated by GR (Kim et al. 1994) and that the level of this antioxidative enzyme was moderately increased under these conditions in the brain cortex and hippocampus of Wistar rats (Filipović and Radojčić 2005), it may be speculated that a simillar antioxidative status could also be expected in liver cells. Further studies are needed to clarify this assumption.

\section{Conflict of Interest}

There is no conflict of interest.

\section{Acknowledgements}

This work was supported by the Ministry of Science and Environmental Protection of the Republic of Serbia, Grants 143042B and 143044B.

\section{References}

ALEXANDROVÁ M: Stress induced tyrosine amino-transferase activity via glucocorticoid receptor. Horm Metab Res 26: 97-99, 1994.

ALEXANDOVÁ M, FARKAŠ P: Stress-induced changes of glucocorticoid receptor in rat liver. J Steroid Biochem Mol Biol 42: 493-498, 1992.

BENJAMIN IJ, MCMILLAN DR: Stress (heat shock) proteins: molecular chaperones in cardiovascular biology and disease. Circ Res 83: 117-132, 1998.

BOONE AN, VIJAYAN MM: Glucocorticoid-mediated attenuation of hsp70 response in trout hepatocytes involves the proteasome. Am J Physiol 283: R680-R687, 2002.

CAAMANO CA, MORANO MI, AKIL H: Corticosteroid receptors: a dynamic interplay between protein folding and homeostatic control. Possible implications in psychiatric disorders. Psychopharmacol Bull 35: 6-23, 2001.

ČVORO A, DUNDJERSKI J, TRAJKOVIC D, MATIC G: Association of the rat liver glucocorticoid receptor with Hsp90 and Hsp70 upon whole body hyperthermic stress. J Steroid Biochem Mol Biol 67: 319-325, 1998.

DEFRANCO DB, QI M, BORROR KC, GARABEDIAN MJ, BRAUTIGAN DL: Protein phosphatase types 1 and/or 2A regulate nucleocytoplasmatic shuttling of glucocorticoid receptors. Mol Endocrinol 5: 1215-1228, 1991.

DONG Y, POELLINGER L, GUSTAFSSON JA, OKRET S: Regulation of glucocorticoid receptor expression: evidence for transcriptional and posttranslational mechanisms. Mol Endocrinol 2: 1256-1264, 1988.

DOUCAS V, SHI Y, MIYAMOTO S, WEST A, VERMA I, EVANS RM: Cytoplasmic catalytic subunit of protein kinase A mediates cross-repression by NF-kappa B and the glucocorticoid receptor. Proc Natl Acad Sci USA 97: 11893-11898, 2000.

DRONJAK S, GAVRILOVIĆ LJ, FILIPOVIĆ D, RADOJČIĆ MB: Immobilization and cold stress affect sympathoadrenomedular system and pituitary-adrenocortical axis of rats exposed to long-term isolation and crowding. Physiol Behav 81: 409-15, 2004.

ELEZ D, VIDOVIĆ S, MATIĆ G: The influence of hyperthermic stress on the redox state of glucocorticoid receptor. Stress 3: 247-255, 2000.

FILIPOVIĆ D, RADOJČIĆ MB: CuZn Superoxide dismutase in the hippocampus and brain cortex of rats exposed to various stress conditions. Ann N Y Acad Sci 1048: 366-368, 2005. 
FILIPOVIĆ D, GAVRILOVIĆ LJ, DRONJAK S, RADOJČIĆ BM: Brain glucocorticoid receptor and heat shock protein 70 levels in rats exposed to chronic, acute or combined stress. Neuropsychobiology 51: 107-114, 2005.

FILIPOVIĆ D, GAVRILOVIĆ LJ, DRONJAK S, RADOJČIĆ BM: The effect of repeated physical exercise on hippocampus and brain cortex in stressed rats. Ann N Y Acad Sci 1096: 207-219, 2007.

GARCIA A, MARTI O, VALLES A, DAL-ZOTTO S, ARMARIO A: Recovery of hypothalamic-pituitary-adrenal response to stress. Effect of stress intensity, stress duration and previous stress exposure. Neuroendocrinology 72: 114-125, 2000.

HASHIGUCHI H, YE SH, MORRIS M, ALEXANDER N: Single and repeated environmental stress: effect on plasma oxytocin, corticosterone, catecholamines and behaviour. Physiol Behav 61: 731-736, 1997.

HENDRICK JP, HARTL FU: Molecular chaperone functions of heat-shock proteins. Annu Rev Biochem 62: 349-384, 1993.

HIGHTOWER LE, HENDERSHOT LM: Molecular chaperones and the heat shock response at Cold Spring Harbor. Cell Stress Chaperones 2: 1-11, 1997.

IMAI E, MINER JN, MITCHELL JA, YAMAMOTO KR, GRANNER DK: Glucocorticoid receptor-cAMP response element-binding protein interaction and the response of the phosphoenolpyruvate carboxykinase gene to glucocorticoids. J Biol Chem 268: 5353-5356, 1993.

JONAT C, RAHMSDORF HJ, PARK KK, CATO AC, GEBEL S, PONTA H, HERRLICH P: Antitumor promotion and antiinflammation: down-modulation of AP-1 (Fos/Jun) activity by glucocorticoid hormone. Cell 62: 11891204, 1990 .

KALINYAK JE, DORIN RI, HOFFMAN AR, PERLMAN AJ: Tissue-specific regulation of glucocorticoid receptor mRNA by dexamethasone. $J$ Biol Chem 262: 10441-10444, 1987.

KASAMBALIDES EJ, LANKS KW: Dexamethasone can modulate glucose-regulated and heat shock protein synthesis. J Cell Physiol 114: 93-98, 1983.

KIM HT, KIM YH, NAM JW, LEE HJ, RHO HM, JUNG G: Study of 5'-flanking region of human Cu/Zn superoxide dismutase. Biochem Biophys Res Commun 201: 1526-1533, 1994.

KVETŇANSKÝ R, MIKULAJ L: Adrenal and urinary catecholamines in rats during adaptation to repeated immobilization stress. Endocrinology 87: 738-743, 1970.

LAEMMLI UK: Cleavage of structural proteins during the assembly of the head of bacteriophage T4. Nature 227: 680685, 1970.

LOWRY OH, ROSEBROUGH NJ, FARR AL, RANDALL RJ: Protein measurement with the Folin phenol reagent. J Biol Chem 123: 265-275, 1951.

MCEWEN BS: Protective and damaging effects of stress mediators. In: Seminars in Medicine of the Beth Israel Deaconess Medical Center. JS FLIER, LH UNDERHILL (eds), Boston, 1998, pp 171-179.

MCKAY LI, CIDLOWSKI JA: Cross-talk between nuclear factor-kappa B and the steroid hormone receptors: mechanisms of mutual antagonism. Mol Endocrinol 12: 45-56, 1998.

MEANEY MJ, VIAU V, BHATNAGAR S, BETITO K, INY LJ, O'DONNELL D, MITCHELL JB: Cellular mechanisms underlying the development and expression of individual differences in the hypothalamicpituitary-adrenal stress response. J Steroid Biochem Mol Biol 39: 265-274, 1991.

OAKLEY RH, CIDLOWSKI JA: Homologous down regulation of the glucocorticoid receptor: the molecular machinery. Crit Rev Eukaryot Gene Expr 3: 63-88, 1993.

OKRET S, POELLINGER L, DONG Y, GUSTAFSSON JA: Down-regulation of glucocorticoid receptor mRNA by glucocorticoid hormones and recognition by the receptor of a specific binding sequence within a receptor cDNA clone. Proc Natl Acad Sci USA 83: 5899-5903, 1986.

PRATT WB, TOFT DO: Steroid receptor interaction with heat shock protein and immunophilin chaperones. Endocr Rev 18: 306-360, 1997.

RIZZA RA, MANDARINO LJ, GERICH JE: Cortisol-induced insulin resistance in man: impaired suppression of glucose production and stimulation of glucose utilization due to a post receptor detect of insulin action. $J$ Clin Endocrinol Metab 54: 131-138, 1982. 
ROSEWICZ S, MCDONALD AR, MADDUX BA, GOLDFINE ID, MIESFELD RL, LOGSDON CD: Mechanism of glucocorticoid receptor down-regulation by glucocorticoids. J Biol Chem 263: 2581-2584, 1988.

ROUSE J, COHEN P, TRIGON S, MORANGE M, ALONSO-LLAMAZARES A, ZAMANILLO D, HUNT T, NEBREDA AR: A novel kinase cascade triggered by stress and heat shock that stimulates MAPKAP kinase-2 and phosphorylation of the small heat shock proteins. Cell 78: 1027-1037, 1994.

SAPOLSKY RM, KREY LC, MCEWEN BS: Glucocorticoid-sensitive hippocampal neurons are involved in terminating the adrenocorticosteroid stress response. Proc Natl Acad Sci USA 81: 6174-6177, 1984.

SAPOLSKY RM, ROMERO LM, MUNCK AU: How do glucocorticoids influence stress responses? Integrating, permissive, suppressive, stimulatory and preparative actions. Endocr Rev 21: 55-89, 2000.

SCHAAF MJ, CIDLOWSKI JA: Molecular mechanisms of glucocorticoid action and resistance. J Steroid Biochem Mol Biol 83: 37-48, 2002.

SILVA CM, POWELL-OLIVER FE, JEWELL CM, SAR M, ALLGOOD VE, CIDLOWSKI JA: Regulation of the human glucocorticoid receptor by long-term and chronic treatment with glucocorticoid. Steroids 59: 436-442, 1994.

SHI Y, THOMAS JO: The transport of proteins into the nucleus requires the 70-kilodalton heat shock protein or its cytosolic cognate. Mol Cell Biol 12: 2186-2192, 1992.

WADEKAR SA, LI D, PERIYASAMY S, SANCHEZ ER: Inhibition of heat shock transcription factor by GR. Mol Endocrinol 15: 1396-1410, 2001.

WALLACE AD, CIDLOWSKI JA. Proteasome-mediated glucocorticoid receptor degradation restricts transcriptional signaling by glucocorticoids. J Biol Chem 276: 42714-42721, 2001.

WANG TT, CHIANG AS, CHU JJ, CHENG TJ, CHEN TM, LAI YK: Concomitant alterations in distribution of 70 $\mathrm{kDa}$ heat shock proteins, cytoskeleton and organelles in heat shocked 9L cells. Int J Biochem Cell Biol 30: 745-759, 1998.

WEBSTER JC, JEWELL CM., BODWELL JE, MUNCK A, SAR M, CIDLOWSKI JA: Mouse glucocorticoid receptor phosphorylation status influences multiple functions of the receptor protein $J$ Biol Chem 272: 9287-9293, 1997.

WRANGE O, OKRET S, RADOJČIĆ M, CARLSTEDT-DUKE J, GUSTAFSSON JA: Characterization of the purified activated glucocorticoid receptor from rat liver cytosol. J Biol Chem 259: 4534-4541, 1984. 